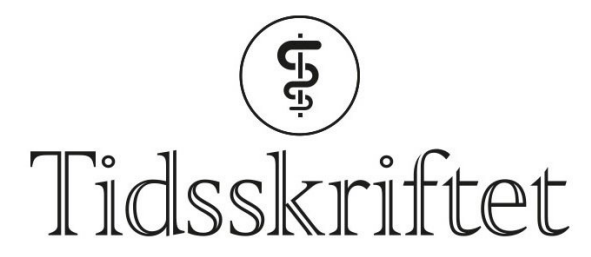

DEN NORSKE LEGEFORENING

\title{
Tarmfloraen forandrer legemidler
}

FRA ANDRE TIDSSKRIFTER

HAAKON B. BENESTAD

Universitetet i Oslo

De fleste medikamenter som tas peroralt, blir trolig metabolisert av bakterier i tarmen.

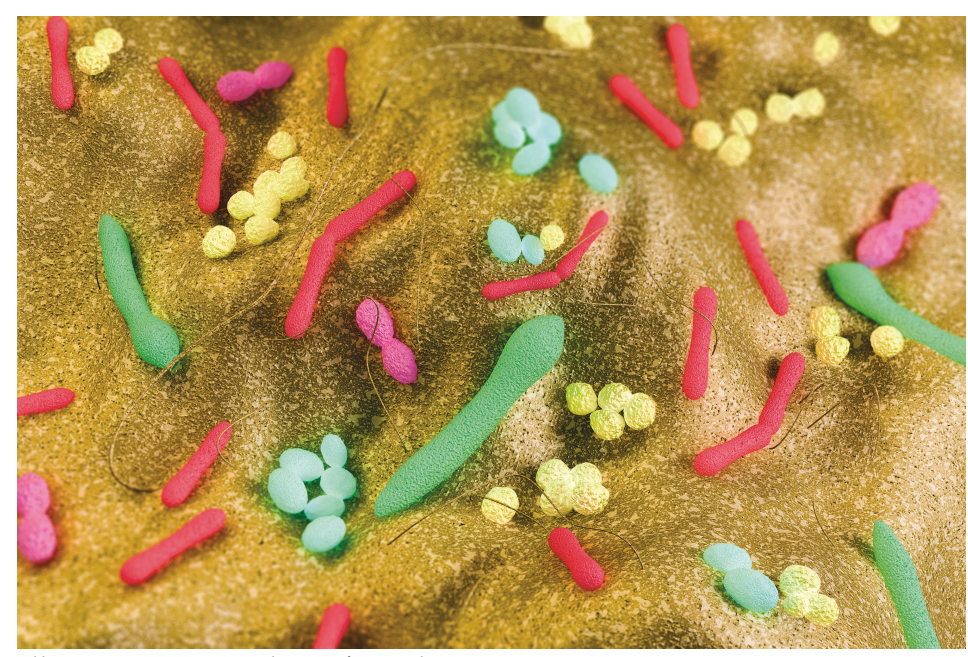

Illustrasjon: jamesbenet/iStock

Medikamenter virker ofte forskjellig på pasienter. Dette kan skyldes individuelt ulike medikamentmetaboliserende leverenzymer. Men også tarmmikrober kan spille en viktig rolle: Prontosil, et antibiotikum, må aktiveres av tarmmikrober til sulfanilamid for å gi klinisk effekt, og levodopa, som brukes mot Parkinsons sykdom, kan inaktiveres i tarmen.

I en bredt anlagt studie ble påvirkningen fra hver av 76 tarmbakteriearter på 271 ulike medikamenter analysert (1). Mikrobe og testsubstans ble inkubert sammen. Ved hjelp av massespektrometri ble det vist hvordan 176 av medikamentene ble omdannet, noen til flere enn én metabolitt, bl.a. gjennom acetylering og deacetylering. Alle bakterieartene kunne omdanne minst ett av medikamentene.

For å påvise mekanismen bak omdannelsen studerte artikkelforfatterne en bakterietype som kunne modifisere kalsiumantagonisten diltiazem. Bakteriegenomet ble kuttet opp og bit for bit ført inn i hver sin Escherichia coli-bakterie ved hjelp av plasmider. De E. coli-klonene som kunne metabolisere diltiazem, hadde da fått en DNA-bit som kunne kode for et metaboliserende enzym, som så kunne identifiseres. Funnet av riktig metaboliserende gen ble validert ved at bakterier der genet var slått ut, ikke lenger kunne metabolisere diltiazem. Forfatterne viste også at individuell variasjon i menneskers tarmmikrobiom kan knyttes til individuelle forskjeller i medikamentmetabolismen. 
- Denne studien kan danne mønster for bedre utvikling av persontilpasset medikamentell behandling, sier Finn Olav Levy, som er professor ved Avdeling for farmakologi ved Universitetet i Oslo og ved Oslo universitetssykehus. Persontilpasset eller skreddersydd medikamentell behandling innebærer at hver pasient skal få individuelt tilpasset legemiddelbehandling, både med tanke på virkning og dosering.

- At tarmbakteriene kan bidra til omsetning av legemidler har vært kjent, men ikke så mye studert. Denne studien har kartlagt dette i en helt annen grad enn tidligere. Persontilpasset legemiddelbehandling må dermed ta hensyn til flere faktorer enn pasientens genetisk bestemte evne til å omsette legemidlene. Måling av serumkonsentrasjon og effekt av legemidler vil derfor fortsatt være viktig, sier Levy.

LITTERATUR:

1. Zimmermann M, Zimmermann-Kogadeeva M, Wegmann R et al. Mapping human microbiome drug metabolism by gut bacteria and their genes. Nature 2019; 570: 462-7. [PubMed][CrossRef]

Publisert: 4. desember 2019. Tidsskr Nor Legeforen. DOI: 10.4045/tidsskr.19.06o5

(C) Tidsskrift for Den norske legeforening 2020. Lastet ned fra tidsskriftet.no 